\title{
REPRESENTASI PANGAN DALAM KOMUNIKASI RITUAL (Kajian Komunikasi Ritual dalam Perayaan Sekaten di Yogyakarta 2015 - 2016)
}

\author{
Oleh: Rosalia Prismarini Nurdiarti \\ Prodi Ilmu Komunikasi Universtas Mercu Buana Yogyakarta \\ E-mail: rosa@mercubuana-yogya.ac.id
}

\begin{abstract}
Food is a part of human civilization. Food is not merely for needs subsistence, but also contains the social, economic and political relations. The phenomenon that shows how adherence of food with our daily life is present in the form of traditional food as uborampe in tradition of Sekaten in Yogyakarta. There, food is a form of culture that is closely related to how humans build messaging, communication and cultural interaction. Food in the Sekaten ritual celebration can not be separated from the socio-historical context surrounding society and culture in Yogyakarta and Java in general.

The results of research shows that the food in the ritual Sekaten represent how the food is more than just the basic necessities, but also it was believed as the part of the berkah (blessing) and be able to give the good fortune for their ancestry until now. Sekaten is organized to commemorate the birth of Nabi Muhammad SAW, which is performed by the king as the local authorities in order to disseminate the Islamic religion and preserve the tradition he inherited. In a worrying global economic situation, including Indonesian (also Javanese society in Jogjakarta), Sekaten still held not only about food but also the high values were contained therein.
\end{abstract}

Keywords: Sekaten, food, symbol, interpretation

\begin{abstract}
Abstrak
Pangan merupakan bagian dari peradaban manusia. Pangan tidak sekedar memenuhi kebutuhan hidup semata, tetapi juga mengandung sebuah relasi sosial, ekonomi dan politik. Fenomena begitu lekatnya pangan dengan kehidupan keseharian kita hadir dalam wujud pangan tradisional sebagai uborampe dalam tradisi Sekaten di Yogyakarta. Di sana, pangan merupakan wujud kebudayaan yang berkaitan erat dengan cara manusia membangun pesan, komunikasi dan interaksi kebudayaan. Pangan dalam ritual syukuran Sekaten, tidak terlepas dari konteks sosiohistoris yang melingkupi masyarakat dankebudayaan Yogyakarta khususnya dan Jawa pada umumnya.

Hasil penelitian menunjukkan bahwa pangan dalam ritual Sekaten merepresentasikan bagaimana pangan lebih dari sekedar kebutuhan dasar, tetapi juga diyakini sebagai bagian dari Berkah dan mampu memberikan rejeki pada anak turun mereka hingga kini. Sekaten diselenggarakan untuk memperingati kelahiran Nabi Muhammad SAW, yang dilakukan oleh raja sebagai penguasa setempat dalam rangka menyiarkan agama Islam dan melestarikan tradisi yang diwarisinya. Dalam situasi ekonomi global yang memprihatinkan termasuk Indonesia (juga masyarakat suku Jawa di Yogyakarta), Sekaten tetap diselenggarakan tidak hanya terkait semata tentang pangan tapi juga nilai-nilai luhur yang terkandung di dalamnya.
\end{abstract}

Kata kunci: sekaten, pangan, simbol, interpretasi. 
Diterbitkan oleh Program Studi IImu Komunikasi

Universitas Ahmad Dahlan Yogyakarta

\section{A. Pendahuluan}

Pesan merupakan komponen yang penting dalam aktivitas komunikasi, pesan berinteraksi dalam kehidupan manusia untuk memproduksi makna. Hal itu berarti menekankan adanya aturan pada pesan atau teks dalam sebuah budaya. Pesan dikemas dalam berbagai bentuk dan disampaikan dengan bermacam cara. Cara manusia menulis, berbicara, berpakaian dan berperilaku. Semua gerak kita mempunyai makna bagi orang lain. Makna muncul ketika manusia menginterpretasikan simbol ${ }^{1}$ yang merupakan salah satu elemen struktural pesan. Interpretasi tersebut dilatarbelakangi oleh pengalaman dan budaya dari pengirim dan penerima pesan, sehingga bisa muncul banyak perbedaan yang itu subyektif sifatnya. Komunikasi merupakan interaksi sosial keseluruhan pesan dengan caranya masing-masing, dimana pada interaksi tersebut menempatkan individu sebagai anggota dari budaya tertentu atau anggota masyarakat.

Dalam mengartikulasikan pesan-pesan tersebut, bisa mewujud dalam berbagai bentuk, yakni bahasa verbal maupun non vebal. Diantara pertukaran pesan tersebut, pertukaran pesan kebudayaan menjadi hal yang penting. Dalam berbagai pandangan kebudayaan, memiliki symbol-simbol atau kepercayaan yang diyakini turun-temurun dan diwariskan pada generasi selanjutnya. Pangan sebagai bagian dari kebudayaan menjadi bagian yang penting untuk diperhatikan, bukan hanya sekedar pada kebutuhan, tetapi juga melihat kehadirannya dalan konteks sosial masyarakat kita. Salah satunya pandangan budaya Jawa, memahami bahwa hal-hal yang berkaitan dengan bahan makanan dan pengobatan tidak dapat dipisahkan dari sistem kepercayaan dan sistem sosial budaya. Demikian pula pada kebanyakan kebudayaan Jawa yang memandang tanaman pangan dan tanaman obat sebagai bagian dari kearifan lokal yang berbasis pada sistem kepercayaan seperti pada masa lalu. Masih adanya keyakinan pada Dewi Sri yang menyimbolkan kesuburan dan kesejahteraan boga.

Makanan dapat dibedakan makanan harian, makanan adat dan tradisi yang berkaitan dengan peringatan daur hidup dan makanan untuk upacara ritual sebagai sesaji. Minuman terdiri dari minuman ringan dalam kegiatan sehari-hari maupun untuk upacara adat dan resepsi, terdapat pula jamu untuk terapi kesehatan dan minuman sehat yang dikomsumsi sebagai minuman segar. Klasifikasi tersebut merupakan identifikasi atas bahan, manfaat dan nilai. Pangan merupakan bagian dari manusia, kebudayaan dan lingkungannya. Dalam perspektif budaya, merupakan sebuah identitas, representasi, dan produksi dari kebudayaan yang berkembang di masyarakat. Pola-pola simbol dalam pangan yang saling berhubungan akan menjadi kekayaan pengetahuan lokal masyarakat yang adaptif dan mampu menciptakan nilai-nilai kultural yang menyimpan kekayaan khasanah suatu kebudayaan.

Menilik sejarah, pada Era Orde Baru telah terjadi 'penyeragaman' pola makan dan keanekaragaman hayati. Hal ini tidak mampu dilepaskan dari arus globalisasi2 yang

${ }^{1}$ Menurut John Powers pesan mempunyai 3 elemen struktural: tanda, simbol, bahasa dan wacana (Littlejohn, 2002: 57)

2 Jika dipandang sebagai proses, globalisasi dapat dimaknai sebagai reduksi hambatan-hambatan bagi pergerakan lintas batas barang, jasa dan modal, meningkatkan aliran komoditi, teknologi, informasi modal, finasial, moda distribusi dan pemasaran serta sampai tingkat tertentu mograsi orang dan tenaga kerja. Ciri utama proses globalisasi adalah penyeragaman praktek dan proses kelembagaan, ekonomi, sosial dan budaya dari 
menginjeksi Indonesia. Tak luput juga globalisasi sistem pangan, yang setidaknya sudah berlangsung ratusan tahun lalu. Seiring dengan perpindahan tumbuhan dan hewan sumber pangan sebagai 'buah' pergerakan manusia menembus batas-batas wilayah. Di Indonesia, kehadiran sejumlah buah dan sayuran segar dan ratusan item pangan olahan impor di hypermarket hingga pasar 'becek' saat ini merupakan salah satu contoh nyata hadirnya fenomena globalisasi pangan (Widianarko, 2006: 8-9). Sayuran dan buah dengan warna dan bentuk yang masih bagus terpajang di etalase mapun lapak-lapak, dan kita tak pernah tahu pengolahan, penyimpanan dan proses tanam seperti apa yang membuat bahan-bahan tersebut masih 'utuh' dan tidak layu saat sampai ke Indonesia.

Berpijak pada persoalan di atas ada dua hal yang penting yang ingin digali yakni, menjelaskan bahwa pangan merupakan wujud kebudayaan yang amat berkait dengan cara manusia membangun pesan, komunikasi dan interaksi kebudayaan. Bagaimana pangan sebagai simbol dan pesan ini pernah hadir dalam wujud pangan tradisional yang ada dalam masyarakat Jawa. Kedua, kemudian mencoba menilik lebih jauh bagaimana alam era modern sekarang pangan tradisional mencoba bertahan dan menunjukkan eksistensinya. Maka peneliti akan memfokuskan pada makna dan representasi pangan dalam ritual syukuran khususnya sekaten, sekaligus tanpa melepaskan konteks sosiohistoris yang melingkupi masyarakat dan kebudayaan Jawa.

\section{B. Tinjauan Pustaka}

\section{Komunikasi Ritual dalam Budaya Jawa}

Komunikasi ritual merupakan bagian dari pemaknaan simbol. Ritual selalu diidentikkan dengan habit (kebiasaan) atau rutinitas. Couldry memahami ritual sebagai suatu habitual action (aksi turun-temurun), aksi formal dan juga mengandung nilai-nilai transendental. Mencermati pandangan-pandangan tersebut, dipahami bahwa ritual berkaitan dengan pertunjukan secara sukarela yang dilakukan masyarakat secara turuntemurun (berdasarkan kebiasaan) menyangkut perilaku yang terpola. Pertunjukan tersebut bertujuan mensimbolisasi suatu pengaruh dalam kehidupan kemasyarakatan (Manafe, 2011: 289).

Komunikasi ritual erat kaitannya dengan komunikasi ekspresif, yang biasanya dilakukan secara kolektif. Suatu komunitas sering melakukan upacara-upacara berlainan sepanjang tahun dan sepanjang hidup, yang disebut antropolog sebagai rites of passage, seperti ritual kelahiran, pernikahan, kematian atau ritual lain yang terkait dengan hari-hari tertentu yang dianggap penting, ataupun ritual sebagai ungkapan syukur. Dalam acaraacara itu, orang mengucapkan kata-kata atau menampilkan perilaku simbolik. Mereka yang berpartisipasi dalam bentuk komunikasi ritual tersebut menegaskan kembali komitmen mereka kepada tradisi keluarga, komunitas, suku, bangsa, negara, ideologi atau agama mereka (Mulyana, 2010: 23).

Upacara atau ritual keagamaan dalam model penjelasan Leach, merupakan jembatan yang menghubungkan dunia empirik (the world of temporal experience) yang

berbagai negara - yang tidak dapat berlangsung serempak (Kennedy, Castells, Caval Canti dalam Widianarko, 2006: 7-8) 
Diterbitkan oleh Program Studi IImu Komunikasi

Universitas Ahmad Dahlan Yogyakarta

dihadapi manusia sehari-hari dengan dunia supranatural, dunia ke-Allah-an (the other world of experience reversed) yang tidak dapat dijangkau akal budi manusia. Dalam konteks budaya Jawa, menurut Herusatoto, simbol merupakan sebuah alat perantara untuk menuliskan segala macam bentuk pesan pengetahuan kepada masyarakat. Simbol-simbol yang ada bertujuan atau mengandung maksud untuk dapat dilihat atau untuk dapat didengar dan diingat dalam sanubari. Sehingga akhirnya dapat dipahami dan dihayati dengan segala macam makna yang terkandung di dalam symbol-simbol tersebut. Simbol dalam konteks budaya Jawa mempunyai fungsi tranformasi sosial, hanya fungsi ini masih 'hipotetik' artinya masih membutuhkan penelitian lebih lanjut. Hal ini berkaitan dengan asal-usul simbol dan bagaimana mentransmisikan makna yang terkandung di dalamnya pada masyarakat, serta bagaimana keterpengaruhan masyarakat hingga terbentuk pola perilaku seperti yang diinginkan sang creator simbol (Haryanto, 2013: 17-18).

Bagi masyarakat Jawa, upacara slametan umumnya merupakan ritual yang menduduki posisi sentral. Upacara ini biasanya diselenggarakan dalam momen-momen khusus yang menyangkut siklus hidup manusia. Selain itu, upacara ini juga diselenggarakan ketika seorang akan melaksanakan pekerjaan penting seperti menanam atau memanen padi, membangun rumah, memulai pekerjaan-pekerjaan yang terkait dengan kepentingan orang banyak (barang publik) seperti membangun jalan, jembatan. Dalam sebuah ritual slametan ini, makanan menjadi unsur yang penting sebab diyakini memiliki nilai 'berkah' tersendiri karena telah didoakan orang banyak Koentjaraningrat mendeskripsikan keadaan slamet, sebagai sebuah keadaan dimana peristiwa-peristiwa mengikuti alur yang telah ditetapkan dengan mulus dan tak satupun kemalangan yang menimpa siapa saja. (Haryanto, 2013: 69-70).

Ritual slametan menurut Geertz dilaksanakan dengan berbagai tujuan, diantaranya memperbaiki sikap nilai-nilai utama, meningkatkan integrasi teritorial secara efektif berbasis struktur sosial, serta untuk memenuhi kebutuhan psikologis bagi koherensi intelektual dan stabilitas emosional di kalangan masyarakat. Slametan sebagai bagian dari 'produk' budaya sarat denga sistem tanda. Budaya bersifat mengekang sekaligus membebaskan, budaya bersifat mengekang dalam arti memberlakukan sebuah sistem signifikansi yang sudah baku atas individu yang terlahir di dalamnya. Sistem ini sebagian besar akan menentukan cara orang memahami dunia sekitar mereka — dari segi bahasa, music, mitos, ritual, sistem teknologi, dan kode-kode lain yang dipelajari dalam konteks sosial. Budaya juga bersifat membebaskan, karena secara paradoks, ia memberikan sumber daya tekstual yang dapat digunakan individu untuk mencari makna yang baru (Danesi, 2011: 47).

\section{Makna Kebudayaan dalam Pendekatan Hermeneutik}

Bagi Geertz kebudayaan memiliki sifat interpretatif, sebagai sebuah konsep semiotik, dan sebagai sebuah "teks". Kebudayaan merupakan sebuah teks maka ia perlu ditafsirkan agar makna yang terkandung di dalamnya dapat ditemukan. Kebudayaan bagi Geertz adalah jaringan makna simbol yang perlu diuraikan dalam sebuah deskripsi mendalam (thick description). Geertz menyatakan bahwa kebudayaan sebagai suatu sistem makna dan simbol, ditransmisikan secara historis, diwujudkan di dalam bentuk-bentuk 
simbolik melalui sarana dimana orang-orang mengkomunikasikan, mengabadikannya dan mengembangkan pengetahuan dan sikap-sikapnya ke arah kehidupan. Dalam penafsiran budaya lingkaran hermeneutic, merupakan gerakan dari konsep pengalaman dekat ke pengalaman jauh. Penafsir budaya sebenarnya menerjemahkan keduanya sehingga pengamat dari luar dapat memahami perasaan dan pemaknaan sebuah anggota budaya dalam sebuah situasi (Littlejohn, 2012: 458).

Konsep kebudayaan simbolik yang dikemukakan oleh Geertz di atas adalah suatu pendekatan hermeneutik yang lazim dalam tradisi strukturalisme. Pendekatan hermeunetik inilah yang kemudian menginspirasinya untuk melihat kebudayaan sebagai teks-teks yang harus dibaca dan diinterpretasikan. Dari Paul Ricoeur, Geertz mengambil gagasan bahwa ilmu pengetahuan manusia yang ada, bukan merupakan kumpulan pengalaman empiris tetapi sebagai suatu struktur fakta yang merupakan simbol dan hukum yang mereka beri makna. Dengan demikian tindakan manusia dapat menyampaikan makna yang dapat dibaca dan merupakan suatu perlakuan yang sama seperti kita memperlakukan teks tulisan (Littlejohn, 2012: 58).

Pentingnya keberadaan simbol membuat Paul Ricoeur menempatkan simbol sebagai fokus utama dalam hermeneutikanya. Lebih lanjut lagi Ricoeur menngemukakan bahwa memaham teks bukan hanya memahami makna yang terkandung di dalam teks itu, melainkan juga lewat teks itu merefeksikan makna hidup kita, karena teks mengacu pada kehidupan, kepada dunia di luar teks itu, Makna teks itu menimbulkan permenungan filosofis. Menurutnya, hermeneutik bukan sekedar merepresentasikan mitos-mitos, melainkan membiarkan mitos itu berbicara pada kita untuk masa kini. Melaluinya dapat dilihat distansi atas teks dan partisipasi ke dalam teks dalam hubungan dialektis. Maka hermeneutik hanya hanya merekonstruksi makna kebudayaan, melainkan juga mencurigai makna sebagaimana dipraktekkan dalam kritik ideologi (Hardiman, 2015: 244, 259, 263).

Menurut pandangan Jawa tentang masyarakat, hubungan-hubungan sosial seperti halnya hubungan kosmis, haruslah tertata dengan baik dan berpadu dalam sebuah keseluruhan harmonis. Hubungan semacam itu terbangun secara hirarkis, orang menduduki posisi status tertentu yang terkait datu sama lain dengan cara yang tidak sederajat secara moral. Dalam eksistensi fenomenalnya mereka wajib menghargai tertib masyarakat, berbakti kepada orang-orang yang lebih tua dan lebih tinggi, serta perlakukan yang lebh rendah dengan tepa selira. Dalam pengertian yang lebih luas, pengasahan batin diri ini dikenal sebagai kebatinan, ataupun olah rasa. Batin yang kuat memungkinkan seseorang tidak terganggu oleh kejadian ataupun dunia fenomenal dan membuat yang bersangkutan menjadi sabar (Mulder, 2001: 90).

Jawa adalah kelompok etnik terbesar di Asia Tenggara. Variasi subkultural di lingkungan orang Jawa sendiri demikian besar. Tradisi Jawa, adalah tradisi yang amat kaya dan dihimpun dari kesusastraan yang merentang, paling kurang selama seribu tahun mulai dari sumber-sumber kuno Sasekerta hingga kisah-kisah babada dan legenda kerajaankerajaan kuno. Orang-orang Jawa membicarakan kehidupan dalam perspektif mitologi wayang. Banyak dari mereka pun menghormati slametan sebagai mekanisme integrasi sosial yang penting, atau sangat memuliakan kewajiban menziarahi makam orang tua dan leluhur mereka. Lebih dari itu, dalam pengertian etis, mereka akan menempa diri sama seriusnya dengan orang Jawa yang mana saja untuk menjadi ikhlas, yakni ketulusan niat. 
Diterbitkan oleh Program Studi IImu Komunikasi

Universitas Ahmad Dahlan Yogyakarta

Hal ini ada kaitannya dengan pemahaman Jawa untuk sepi ing pamrih, yakni tidak diarahkan oleh tujuan-tujuan egoistik, menempatkan kepentingan orang lain atas kepentingan diri sendiri (Mulder, 2001: 9-10)

\section{Metode Penelitian}

Dalam penelitian ini menggunakan paradigma interpretif, dengan pendekatan hermeneutika. Salah satu cabang hermeneutika adalah tindakan manusia (hermenutika sosial). Memahami masyarakat dalam konteks 'hermeneutic' adalah memahami berbagai nilai, kepentingan, motivasi, keinginan dan juga sejarah hidupnya yang kompleks. Gagasan umum dari proses general pendekatan ini disebut lingkaran hermeneutika. Menurut Ricouer, lingkaran hermeneutika terdiri atas penjelasan yang bersifat empiris dan analitis, berlaku bagi kejadian yang berhubungan dengan pola-pola yang diamati diantara bagian tersebut. Tidak ada satupun dari elemen-elemen pembentuk ini yang memiliki makna di dalam dan mengenai dirinya sendiri, elemen tersebut harus digabungkan dalam tahapan pemahaman penafsiran untuk membentuk pola-pola yang memiliki makna. Pada aspek berikutnya adalah pemahaman yang merupakan sintetis, digunakan untuk kejadiankejadian yang berhubungan dengan keseluruhan penafsiran. Bergerak dari pemahaman ke penjelasan dan kembali pada pemahaman lagi dalam sebuah lingkaran tanpa akhir (Littlejohn \& Foss, 2012: 195-197).

Hermenutika mendalam adalah kerangka metodologi yang luas, yang memuat tiga fase dasar. Tiga fasetersebut adalah analisa sosial historis, analisa formal atau diskursif dan interpretasi/reinterpretasi. Pemikiran ini terkait erat dengan poin penting yang dipaparkan Ricoeur bahwa tugas hermeneutika memiliki tahapan-tahapan langkah, yakni 'langkah simbolik' atau 'pemahaman simbol'. Langkah kedua adalah pemberian makna oleh simbol serta penggalian secara cermat atas makna. Tahap ketiga adalah berpikir menggunakan simbol sebagai titik tolaknya. Tujuan analisa sosial-historis adalah mengkonstruksi kondisi sosial dan historis dari produksi, sirkulasi dan resepsi bentukbentuk simbol. Tugas lain dari fase pertama ini adalah untuk mengamati aturan, relasi dan institusi sosial, juga distribusi keuasaan, sumber daya dan peluang yang mendasari suatu konteks dalam membentuk bidang struktur yang berbeda (Narwaya, 2010: 48).

\section{Pembahasan}

\section{Ritual Sekaten: Rekam Jejak Sejarah ${ }^{3}$}

Sekaten dan Garebeg sudah ada sejak berdirinya kerajaan Demak atau Bintara sebagai kerajaan Islam pertama di Jawa. Pemrakarsanya adalah para wali penyiar agama Islam di Jawa dengan persetujuan dari Raja Demak pertama Raden Patah (1500-1518). Kata garebeg, grebeg, gerbeg, dalam bahasa Jawa bermakna suara angin menderu. Suatu prosesi yang diiringi atau diantar oleh orang banyak. Sekaten merupakan peringatan hari

\footnotetext{
${ }^{3}$ Diadaptasi dari Rintaiswara \& Widyabudaya. 2011. Sangu Sowan. Keraton Yogyakarta (p. 21-23)
} 
lahir Muhammad SAW- yang semula diselenggarakan di halaman masjid Demak dengan membunyikan gamelan Kyai Sekati dari Kerajaan Majapahit.

Perayaan Sekaten diakhiri dengan upacara Garebeg, yaitu keluarnya sedekah raja atau selamatan negara yang dibawa dari masjid keraton ke masjid besar, lalu diserahkan ke Kyai Pengulu demi keselamatan raja dan kawula. Pelaksanaan upacara Grebeg tempo dulu yang dimulai sejak dasawarsa ketujuh abad ini, berawal dari sebuah penyakit yang membutuhkan hewan kurban. Perayaan tersebut sebenarnya untuk menghilangkan wabah penyakit yang meresahkan masyarakat dan kerajaan. Perayaan akhirnya dilakukan setiap tahun, dalam penyelenggaraannya dari tahun ke tahun semakin semarak dengan tetap mempertahankan tradisi yang sudah ada sebelumnya. Pelaksanaan upacara Grebeg Maulud dipimpin oleh Pengageng Panarauitan yang merupakan utusan dari Keraton.

Istilah Garebeg dalam bahasa Jawa berarti berjalan bersama atau mengiringi atau berjalan di belakang raja. Uapacara Garebeg yaitu upacara ritual keluarnya hajad, alam gunungan yang merupakan sedekah-selamatan yang dikeluarkan oleh raja sebagai rasa syukur dan permohonan kepada Tuhan untuk keselamatan dari keluraga dan kawula negara.

Hajad ini terdiri dari banyak makanan dan hasil bumi yang dibentuk seperti gunung, jadi disebut gunungan. Gunungan setelah diterima Kyai Pengulu, lalu didoakan terus dibagi-bagikan kepada kawula yang hadir.

Namun sekarang tidak sempat dibagikan, melainkan langsung diambil ramai-ramai atau dirayah pengunjung. Ada 5 gunungan ditambah satu, yang satu dikirim ke Pura Paku Alaman. Pada Garebeg Besar hanya ada satu gunungan kakung/jejer, sedangkan Garebeg Besar/Idul Adha hajad dalem gunungan ada lima buah. Khusus untuk tahun DAL pada Garebeg Mulud hajad dalem gunungan ditambah satu gunungan yang mengepulkan asap disebut dengan gunungan Brama atau gunungan Kutug. Gunungan Brama setelah sampai di halaman masjid besar lalu dibawa masuk ke keraton lagi dan dibagi khusus untuk para keluarga raja atau para Sentana Dalem.

Pada acara garebeg tersebut ada beberapa barang dan makanan tradisional yang dijual. Beberapa diantaranya nasi uduk atau nasi gurih, kinang racikan makan sirih, telur merah sundukan dan pecut. Selain itu tentunya ubarampe dari gunungan yang didapat dengan susah payah. Benda-benda tadi dipercaya membawa keberuntungan. Orang Jawa menebutnya dengan ngalap berkah. Secara khusus pada perayaan Garebeg Dal, Sultan akan membagikan nasi yang ditanak bersama Ratu Hemas dengan menggunakan periuk pusaka Kyai Mrica. Para petinggi, rayi dalem dan abdi dalem yang berkumpul dalam pisowanan Garebeg Dal, akan memperoleh pembagian nasi yang dikepal-kepal sendiri oleh Ngarsa Dalem.

\section{Pemaknaan Sekaten: Analisas Formal dan Sosio Historis}

Prosesi ini bukan hanya sekedar perayaan tetapi dalam pelaksanaan tertentu memperhatikan keseimbangan alam. Masyarakat memiliki kepercayaan tertentu, yang berhubungan dengan supranatural, masyarakat tidak menyadari makna apa yang ada di balik kepercayaan itu. Sekalipun kepercayaan itu sepintas lalu bersifat takhyul dan tidak masuk akal, namun apabila direnungkan ternyata memiliki tujuan tertentu, yang tidak disadari oleh kebanyakan orang, misalnya kepercayaan orang Jawa yang tabu ketika 
Diterbitkan oleh Program Studi IImu Komunikasi

Universitas Ahmad Dahlan Yogyakarta

menebang pohon besar di dekat kuburan, memperlakukan barang atau sesuatu pusaka (keris dan tombak dengan diperlakukan tidak sewajarnya). Masyarakat percaya adanya kekuatan gaib yang mencelakakan apabila larangan itu dilanggar, sehingga seringkali memberikan sesaji, membakar kemenyan, menempatkan bunga (kembang setaman) dan sebagainya (Sunoto dalam Sari, 2014: 4).

Dari pandangan Mulder, pandangan Jawa tentang masyarakat, hubunganhubungan sosial seperti halnya hubungan kosmis, haruslah tertata dengan baik dan berpadu dalam sebuah keseluruhan harmonis. Dalam eksistensi fenomenalnya mereka wajib menghargai tertib masyarakat, berbakti kepada orang-orang yang lebih tua dan lebih tinggi, serta perlakukan yang lebih rendah dengan tepa selira. Dalam pengertian yang lebih luas, pengasahan batin diri ini dikenal sebagai olah rasa. Batin yang kuat memungkinkan seseorang tidak terganggu oleh kejadian ataupun dunia fenomenal dan membuat yang bersangkutan menjadi sabar. Jawa adalah 'pusat batin' negeri ini, sebagai 'pusat batin' tentunya bisa dikatakan Jawa mendominasi negeri ini (Mulder, 2001: 90).

Upacara atau ritual keagamaan dalam model penjelasan Leach, merupakan jembatan yang menghubungkan dunia empirik (the world of temporal experience) yang dihadapi manusia sehari-hari dengan dunia supranatural, dunia ke-Allah-an (the other world of experience reversed) yang tidak dapat dijangkau akal budi manusia. Ketika perarakan gunungan sampai di Masjid Besar Kauman, masyarakat yang mengikuti prosesi tersebut berebut "rayahan" untuk mendapatkan makanan yang ada dalam gunungangunungan tersebut. Hal tersebut bisa dilihat dari pengalaman salah seorang dari Magelang, Parjo dan keluarganya yang mendapatkan kacang panjang dan beberapa genggam padi (gabah). Menurutnya, hasil "rayahan" tersebut akan diletakkan di warungnya supaya mendatangkan rejeki bagi usahanya.

Hal tersebut sejalan dengan apa yang dikemukakan oleh Lech bahwa Sekaten sebagai bagian dari upacara keagamaan diyakini sebagai bagian yang menjembatani antara dunia empirik (usaha warung Parjo) dan dunia supranatural, yakni keyakinan dia akan agama yang dianut. Berkah yang diperoleh dari hasil "rayahan" sebagai bagian dari simbol yang menunjukkan keprcayaannya pada Sang pemberi hidup. Proses Garebeg adalah yang paling dinantikan oleh warga, karena dalam kegiatan ini akan keluar hajad dalem yakni keluarnya berjenis gunungan dari keraton ke masjid. Gunungan (pareden) merupakan perwujudan kucah dlem (sedekah raja) untuk rakyat. Pada upacara garebeg gunungan yang disediakan sedikitnya 6 buah, terdiri dari; 2 gunungan kakung, 1 gunungan putri, 1 gunungan darat, 1 gunungan pawuhan dan 1 gunungan gepak.

\section{Interpretasi Perayaan Sekaten}

Pada hakekatnya, penyelenggaraan upacara tradisional mengandung suatu ajaran yang diwujudkan dalam bentuk simbol atau lambang yang mana lambang tersebut mempunyai makna. Dalam upacara tradisional sekaten, tentu saja terdapat lambang yang mempunyai makna. Dalam upacara sekaten, pada tahap gamelan pusaka pertama kali dibunyikan, diselenggarakan upacara udhik-udhik, yaitu penyebaran kepingan uang logam oleh Sri Sultan. Pemberian atau penyebaran kepingan uang logam oleh raja ini sebagai lambang bahwa pemberian anugerah berwujud harta dan berkat wujud tuah kekeramatan. 
Upacara numplak wajik sebagai pertanda permulaan pembuatan gunungan secara resmi. Upacara numplak wajik diselenggarakan empat hari menjelang penyelenggaraan upacara garebeg, yaitu pada tanggal 8 bulan Mulud.

Namun, Upacara Sekaten hari ini lebih didominasi oleh keramaian sekaten yang lebih dikenal dengan nama Pasar Malam Sekaten, yang sebenarnya memberi peluang untuk berdagang, berusaha, menjual jasa, dan sebagainya. Ciri khas dari Pasar Malam Sekaten ini adalah banyaknya orang yang menjual kinang (kapur sirih), nasi uduk (sega wuduk), ani-ani (pemotong padi), pecut (cemeti). Di antara sekian banyak penjual dan pembeli barang-barang tersebut, mereka meyakini adanya pengaruh magis dari barang-barang itu. Sebagian dari mereka mengunyah kinang bersamaan dengan pertama kali dibunyikannya gamelan sekaten akan menjadikan awet muda. Kemudian membunyikan pecut-pecut bersamaan dengan drel (bunyi tembakan salvo) prajurit keraton, dan perempuan menyelipkan ani-ani pada sanggul mereka masing-masing, maka dipercaya dapat melipatgandakan ternak dan hasil panen berlimpah (Taryati, 2009: 509).

Berdasarkan hasil observasi peneliti, dalam perkembangannya, Pasar Malam Perayaan Sekaten (PMPS) menjadi ajang promosi dari segala macam jenis produk. Ajang promosi ini sepertinya kebablasan sehingga tidak mengingat lagi esensi dari penyelenggaraan keramaian ini. Pasar Malam ini dimaksudkan untuk menyemarakkan Upacara Sekaten atau Upacara Garebeg Mulud. Oleh sebab itu kegiatan ini jangan sampai menyaingi apalagi mengalahkan tujuan utama. Seperti yang terlihat saat ini yang seharusnya suara gamelan sekaten mendominasi, tetapi kenyataannya malah kalah dengan hiruk pikuk suara musik di Pasar Malam. Kemudian bangunan pada pasar malam seharusnya dibuat jangan sampai mengganggu kegiatan upacara sekaten dan juga harus menghormati keberadaan keraton dengan "tata cara aturan-aturannya".

Upacara Sekaten merupakan medium bertemunya penguasa dengan rakyat, dan rakyat dengan sesamanya ini, pihak penguasa (keraton/yang diikuti rakyat) tidak hanya menunjukkan, melainkan juga meneladani baik dalam berbudaya (ekonomi, politik, hukum, seni, dan sebagainya) maupun dalam beragama (Islam, Iman dan Iksan). Dengan keteladanannya, sekaligus seorang penguasa harus mampu mengarahkan rakyatnya kepada kebaikan dan kebenaran. Aspek penting dari sekaten saat ini adalah implementasinya syahadatain dalam konteks bermasyarakat, aura-aura Ketuhanan dan Ke-Muhammad-an menjadi diri dalam masyarakat, baik dalam perpolitikan, kesenian, ekonomi dan kebudayaan.

Disebutkan pula bahwa hal ini oleh KH. A. Musthafa Bisri disebut "Kesalehan Sosial", yaitu saleh dalam berpikir, dalam bertindak dan berekspresi. Jadi kepentingan sekaten bukan hanya moment pasar, tetapi tetap berdiri dalam makna ritualitas kongkrit yang mengandung kekuatan spiritual. Oleh karena itu, saat ini unsur da'wah dalam rangkaian sekaten perlu dibenahi, yaitu mengemas model-model yang tidak hanya dilakukan di Masjid Agung saja. Penting ditingkatkan adalah jangan hanya tontonan saja tetapi yang lebih penting adalah tuntunannya. Irwan Abdullah menambahkan bahwa Upacara Sekaten mengandung nilai kultural, karena penyelenggaraan upacara ini menyangkut kedudukan Sultan sebagai pemimpin sukubangsa Jawa yang mewarisi leluhurnya dan mengemban mandat untuk melestarikannya. Tradisi turun temurun dari nenek moyang 
Diterbitkan oleh Program Studi IImu Komunikasi

Universitas Ahmad Dahlan Yogyakarta

ini, dalam perjalananya banyak mengalami perubahan bentuk atau sifat (Taryati: 2009, Haryanto; 2013).

Tradisi sekaten merupakan salah satu wujud peninggalan kebudayaan. Menurut Heddy Shri Ahimsa Putra bahwa pewaris kebudayaan dari satu generasi ke generasi berikutnya dimungkinkan karena adanya proses belajar lewat simbol-simbol yang kemudian menjadikan kebudayaan sebagai miliknya. Sejalan dengan hal tersebut Kroeber dan Klucshohn dalam Keesing menyebutkan bahwa kebudayaan adalah warisan sosial yang hanya dapat dimiliki oleh warga masyarakat pendukungnya dengan jalan mempelajarinya melalui simbol-simbol. Disebutkan pula bahwa ada cara-cara mekanisme tertentu dalam masyarakat untuk memaksa tiap warganya mempelajari kebudayaan, yang didalamnya terkandung norma-norma serta nilai-nilai yang berlaku dalam tata pengalaman masyarakat. Hal ini menjadi ciri khas termasuk perwujudannya dalam benda-benda budaya dan menjunjung tinggi nilai itu demi kelestarian hidup bermasyarakat (Hoed; 2011, Haryanto; 2013).

Dari interpretasi simbol yang terlihat dalam Upacara Sekaten, ujud gunungan tersebut adalah gambaran tentang kehidupan atau pandangan hidup orang Jawa. Gambaran ini merupakan konsepsi yang digunakan sebagai pedoman dari cara-cara bertindak atau bertingkah laku orang Jawa. Sistem gagasan ksatria utama adalah gambaran orang yang suka bekerja keras. Berpikiran tajam dan selalu waspada, memiliki rasa alus tingkah lakunya, berani dan menempatkan posisinya dengan benar. Simbol berperan dalam upacara sebagai alat penghubung antara sesama manusia dan antara manusia dengan benda, dan antara dunianya dengan dunia gaib. Dengan demikian tranformasi nilai budaya luhur tetap relevan sepanjang jaman. Upacara Sekaten merupakan modal budaya yang penting untuk dipertahankan dan mampu menghadirkan berbagai inspirasi dalam memori kolektif masyarakat.

\section{E. Kesimpulan dan Saran}

\section{Kesimpulan}

Perayaan Sekaten mengandung nilai-nilai dan ajaran luhur. Perayaan Sekaten, selain perlu dilaksanakan oleh pewaris dan pembawa amanah dari generasi berikutnya, juga penting bagi masyarakat Yogyakarta, karena di samping melaksanakan tugas melestarikan kebudayaan, juga member berkah bagi masyarakat, sebab dapat memberi peluang berkarya dan berusaha dalam upayanya menaikkan kesejahteraan dan kebahagiaan hidup. Hal ini karena Perayaan Sekaten mengandung nilai ekonomi, nilai sosial dan nilai kepariwisataan.

Sekaten juga mengandung nilai sosial karena dalam penyelenggaraannya banyak melibatkan instansi-instansi terkait yaitu keraton, pemerintah kota dan masyarakat. Dengan demikian terjadi kerjasama dan hubungan sosial yang baik antara penyelenggara dan pendukung sehingga saling merasa memiliki kegiatan tersebut. Situasi ini saling mendukung dan membutuhkan dalam hubungan yang harmonis, ini perlu dilestarikan. Sedang hajad dalem dianggap perekat antara raja dan rakyat dan ujud pernyataan setiap individu dalam mengukuhkan diri sebagai bagian dari masyarakat. 


\section{Saran}

Pengelolaan perayaan sekaten diharapkan tetap mengedepankan subtansi ritual budaya dan mengesampingkan kepentingan bisnis. Saat ini pengelolaan sekaten membutuhkan visi kultural yang jelas dan kemampuan managerial. Visi kultural tampak pada capaian-capaian estetis, etis, saintis yang inovatif, serta fungsional yang dihadirkan secara populis. Oleh karena itu harus bisa memilih antara nilai fakultatif dan esensi dari sekaten itu sendiri. Biarlah nilai fakultatif sesuai dengan modernisasi (yaitu di pasar malam atau perayaan) akan tetapi nilai esensinya (yaitu peringatan Maulid Nabi Muhammad SAW) tetap dipertahankan.

\section{Daftar Pustaka}

Danesi, Marcel. 2011. Pesan, Tanda dan Makna: Buku Teks Dasar Mengenai Semiotika dan Teori Komunikasi. Yogyakarta. Jalasutra.

Hardiman, Budi. 2015. Seni Memahami: Hermeneutik dari Schleiermcher Sampai Derrida. Yogyakarta. Kanisius

Haryanto, Sindung. 2013. Dunia Simbol Orang Jawa. Yogyakarta. Kepel Press.

Hoed, Benny. 2011. Semiotik dan Dinamika Sosial Budaya. Jakarta. Komunitas Bambu.

Littlejohn, Stephen W \& Foss, Karen. 2012. Teori Komunikasi. (terj.). Jakarta. Salemba Humanika.

Littlejohn, Stephen W. 2002. Theories of Human Communication. Seventh Edition. Belmont California. Wadsworth Publishing Company.

Manafe, Yermia. 2011. Komunikasi Ritual pada Budaya Bertani Atoni Pah Meto di TimorNusa Tenggara Timur. Jurnal Komunikasi. Vol. 1, No, 3/2011. P. 287-298

Mulder, Niels. 2001. Mistisisme Jawa, Ideologi di Indonesia. Yogyakarta. LkiS.

Mulyana, Deddy. 2009. Komunikasi Suatu Pengantar. Bandung. Remaja Rosdakarya

Narwaya, Guntur. 2010. Kuasa Stigma dan Represi Ingatan. Yogyakarta. Resist Book.

Sari, Devi. 2014. Kajian Nilai Max Scheler dalam Upacara Grebeg Maulud Keraton Surakarta. Skripsi tidak dipublikasikan Fakultas Ilmu Sosial dan Politik Universitas Gadjah Mada Yogyakarta.

Taryati. 2009. Nilai - Nilai yang Terkandung dalam Perayaan Sekaten Yogyakarta. Jurnal Jantra, Jurnal Sejarah dan Budaya. Tahun IV, No, 7/ 2009. P. 506 - 522

Widianarko, Budi. 2006. Dua Wajah Globalisasi Pangan. Jurnal Renai, Kajian Politik Lokal dan Sosial - Humaniora. Tahun VI, No, 2/ 2006. P. 6-21

Widyabudaya \& Rintaiswara, 2011. Sangu Sowan. Keraton Yogyakarta. 